\title{
Ezetimibe and vascular endothelial function
}

Satoshi Ikeda, MD, PhD, and Koji Maemura, MD, $\mathrm{PhD}$.

Department of Cardiovascular Medicine, Nagasaki University Graduate School of Biomedical Sciences, Nagasaki, Japan

Corresponding author: Koji Maemura, $\mathrm{MD}, \mathrm{PhD}$

Department of Cardiovascular Medicine

Nagasaki University Graduate School of Biomedical Sciences

1-7-1 Sakamoto, Nagasaki 852-8501, Japan

Tel: +81-95-819-7288; Fax: +81-95-819-7290

E-mail: maemura@nagasaki-u.ac.jp 


\begin{abstract}
Hypercholesterolemia is a major risk factor for cardiovascular diseases that has been managed mostly with 3-hydroxy-3-methyl glutaryl coenzyme A reductase inhibitors (statins) that suppress de novo cholesterol synthesis in the liver. Statins also have beneficial pleiotropic effects on the atherosclerotic process that are independent of their ability to lower lipid values. However, the levels of low-density lipoprotein cholesterol (LDL-C) in most hypercholesterolemic patients at high risk for cardiovascular disease do not reach the goals proposed by guidelines even when prescribed with statins. Ezetimibe is a new lipid-lowering agent that blocks the intestinal absorption of dietary and biliary cholesterol and reduces LDL-C levels, especially when combined with statins. However, its effect on cardiovascular events remains unknown. We reviewed the effects of ezetimibe on cardiovascular diseases, in particular, vascular endothelial function, which is initially impaired during the atherogenetic process and an important predictor of cardiovascular events. Increasing evidence suggests that ezetimibe improves endothelial function and nitric oxide availability, and reduces inflammation as well as oxidative stress. However, this mechanism has not been clarified and limited, large trials and cohort studies have not shown that this agent prevents cardiovascular events. Ezetimibe has just recently become commercially available, which might explain the paucity of evidence regarding its benefits and effects on cardiovascular morbidity and mortality.
\end{abstract}

\title{
Key words
}

nitric oxide, C-reactive protein, oxidative stress, cardiovascular disease, atherosclerosis 


\section{Introduction}

Cardiovascular diseases based on atherosclerosis comprise one of the most frequent causes of worldwide mortality [1]. The initiation of atherosclerotic disease is closely related to prolonged dyslipidemia, and reducing levels of low-density lipoprotein cholesterol (LDL-C) is a cornerstone in minimizing cardiovascular events in high-risk patients. Guidelines from the National Cholesterol Education Program (NCEP) Adult Treatment Program (ATP) III in the United States [2] and the Joint Task Force of European and other Societies on Cardiovascular Disease Prevention in Clinical Practice in Europe [3] continue to identify elevated LDL-C as the primary target for lipid-modifying therapy. Furthermore, the subsequent ATP-III update in 2004 suggested that the optimal LDL-C level in high-risk individuals might be lower $(<70$ $\mathrm{mg} / \mathrm{dl})$ than that of current treatment guidelines $(<100 \mathrm{mg} / \mathrm{dl})[4]$. Despite these guidelines, many hypercholesterolemic patients on lipid-lowering therapy do not achieve the recommended LDL-C goals $[5,6]$. This treatment gap is particularly evident among high-risk patients with coronary heart disease (CHD). Foley et al. [7] demonstrated that $52 \%$ of high-risk hyperlipidemic patients did not achieve the LDL-C goal with an initial dose of 3-hydroxy-3-methylglutaryl coenzyme A (HMG-CoA) reductase inhibitors (statins), and that $86 \%$ of these patients had still not reached the goal after 6 months. Dembowski et al. showed that only $18 \%$ of these patients achieved the LDL-C treatment goal with statin monotherapy [8]. One reason is that the initiation dose of statins is most effective and doubling the dose achieves only a $6 \%$ additional reduction in LDL-C levels [9].

Statins lower cholesterol through inhibiting cholesterol synthesis. However, the intestinal absorption of dietary and biliary cholesterol is also a major source of 
cholesterol that affects lipid profiles [10]. Therefore, the inhibition of cholesterol absorption in the intestine is considered to be a potentially complementary component of lipid management. Ezetimibe was discovered as a potential inhibitor of acylcoenzyme A: cholesterol acyltransferase and it is the first cholesterol absorption inhibitor to actually inhibit biliary and dietary cholesterol absorption from the small intestine. This agent specifically blocks the cholesterol transporter, Niemann-Pick-like protein 1 , which is enriched in the brush border membrane of the small intestine. The inhibition of cholesterol absorption consequently decreases cholesterol delivery to the liver, reduces hepatocyte cholesterol stores, increases liver expression of LDL receptors and increases serum LDL production and clearance, resulting in a fall in serum LDL-C levels [11,12]. Ezetimibe reduces cholesterol absorption by 40 to $50 \%$ [13], and it reduces LDL-C levels by about 18\% [14]. Co-administration of ezetimibe and statin significantly reduces LDL-C levels by 18 to $25 \%$ compared to statin monotherapy [15]. This synergistic effect can help more patients with hyperlipidemia to achieve LDL-C targets. Gagne et al. [16] reported that only $19 \%$ of patients reach treatment goals on statin monotherapy whereas adding ezetimibe increases this proportion to $72 \%$. This might result in a decrease in the incidence of future cardiovascular events.

Impaired vascular endothelial function is one initial step in the progress of atherosclerosis, which leads to the development of cardiovascular disease. Therefore, endothelium dysfunction is an important predictor of cardiovascular events. This chapter reviews the effects of ezetimibe on endothelial function.

\section{Endothelial function}

The vascular endothelium is a continuous layer of cells that separates blood from 
vessel walls and it plays an important role in many physiological functions including the regulation of vasomotor tone and the maintenance of vascular homeostasis [17-25]. These processes involve the production of vasoconstrictive and vasodilating factors from endothelial cells. Endothelium-derived relaxing factors comprise nitric oxide (NO), prostacyclin and endothelium-derived hyperpolarizing factor. Nitric oxide is very important and it is mediated by the endothelium isoform of NO synthase (endothelial NO synthase, eNOS). The production of NO derived via eNOS protects the endothelium from vascular damage by inhibiting vascular smooth muscle cell proliferation, platelet and leukocyte activation and adhesion, oxidative stress and the degranulation of proinflammatory vesicles. In addition, NO inhibits both the release and action of endothelin-1, a potent vasoconstrictive peptide in the endothelium, which facilitates a proatherogenic phenotype [24-30]. Thus, NO plays a pivotal role in maintaining endothelial structural integrity and functional activity, which subsequently protects against the development of atherosclerotic vascular disease. Despite the importance of the intact endothelium and the maintenance of endothelial integrity, the regenerative capacity of mature endothelial cells is limited. Interest in endothelial progenitor cells (EPCs) is increasing [31-34], because they are precursors of mature endothelial cells originating from the bone marrow, replenish damaged endothelial cells, and migrate to sites of ischemia where they participate in neovascularization and collateral development [35-39], processes that also involve NO. An experimental study has shown that NO derived from bone marrow is pivotal to EPC mobilization from this source. Moreover, eNOS activation is thought to mediate vascular endothelial growth factor (VEGF)-induced EPC mobilization [40-42]. These results indicate that eNOS-derived NO production is crucial for maintaining endothelial health. 
The bioavailability of vasodilators, especially NO is reduced, whereas that of endothelial-derived contracting factors is increased in endothelial dysfunction. This imbalance predisposes the vasculature to vasoconstriction, leukocyte adhesion, platelet activation, pro-oxidation, thrombosis, inflammation and atherosclerosis $[23,25,43]$. Endothelial dysfunction probably precedes the clinical manifestations of cardiovascular disorders such as hypertension, dyslipidemia, and diabetes. Cholesterol levels have an intimate and linear relationship with coronary artery disease risk. Endothelium-dependent vascular relaxation is impaired and vascular superoxide production is increased in hypercholesterolemic apoE-knockout mice. This is due to a deficiency of tetrahydrobiopterin (BH4), an essential cofactor for NOS in the aortas of these knockout mice compared to wild-type mice, but dietary BH4 supplementation appears to reduce superoxide production and restore NO synthesis [44]. Reduced levels of BH4 induce "eNOS uncoupling", with the resultant production of superoxide, leading to endothelial dysfunction $[25,45]$. Moreover, increased superoxide generation might also promote increased LDL oxidation, which exerts further endothelial damage mediated by the generation of peroxynitrite and hydroxy radicals [46]. Endothelial progenitor cells are also impaired and their numbers inversely correlate with these conditions. Oxidized LDL dose-dependently decreases EPC survival and its adhesive, migratory, and tube-formation capacities [47]. Endothelial dysfunction is associated with future cardiovascular events and is clinically detectable as blunted vasodilation in response to acetylcholine or hyperemia, both of which produce eNOS-dependent vasodilation. Hedblad et al. [48] discovered that lower pulse-wave amplitude during reactive hyperemia in the calf muscle with venous occlusion determined by plethysmography is associated with a higher probability of cardiac events and all-cause 
mortality. Studies of forearm arterial responses to acetylcholine infusion or hyperemia have revealed that impaired endothelial function is an independent predictor of cardiovascular events [49-51]. All of these findings indicate that endothelial dysfunction is a key early step in atherogenesis and that it can serve as a predictor of cardiovascular morbidity and mortality.

Endothelial dysfunction is reversible, and strategies for reducing cardiovascular risk factors, such as cholesterol lowering [52], blood pressure lowering [53], smoking cessation [54], physical exercise [55], and estrogen replacement therapy for post menopausal women [56] can improve endothelial function.

Hypercholesterolemia is one of the most important risk factors for cardiovascular disease because LDL-C, especially oxidized LDL, contributes to the initiation of plaque formation from the early stage of atherogenesis [57,58]. During this process, protein kinase $\mathrm{C}$ and nuclear factor kinase-kB (NF-kB) are initially activated in cells, where they up-regulate the local production of angiotensin II, as well as the expression of enzymes that produce oxidative stress as well as endothelial cell surface adhesion molecules [59]. These play key roles in the development of endothelial dysfunction. Lipid lowering per se is associated with improved endothelial function regardless of the choice of therapeutic strategy; for example, LDL apheresis improves endothelial-dependent vasodilation [60].

Statins are potent lipid-lowering agents and considerable evidence shows that statins have beneficial pleiotropic effects on cardiovascular diseases that are independent from their lipid-lowering effects [61-64]. These involve improved endothelial function, attenuation of the inflammatory process and normalization of the coagulation system, leading to a reduction in cardiovascular disease morbidity and 
mortality [64]. The anti-inflammatory properties of statins that are independent of cholesterol-lowering have recently been announced as the primary objective of the Justification for the Use of Statins in Prevention and Intervention Trial Evaluating Rosuvastatin (JUPITER). This trial enrolled 17,802 healthy individuals without hyperlipidemia but with elevated high-sensitivity CRP (hs-CRP) levels and followed cardiovascular events for a median of 1.9 years (maximum 5.0 years). The results showed that rates of a major cardiovascular event and death from any cause were significantly reduced among participants who received rosuvastatin as compared to those who received a placebo [65]. Although the mechanisms of the pleiotropic effects by statins are not fully understood, the following have been considered. The enzyme HMG-CoA reductase plays a pivotal role not only in cholesterol synthesis but also in the synthesis of isoprenoids such as farnesyl pyrophosphate and geranylgeranyl pyrophosphate. These isoprenoids serve through prenylation as important lipid attachments for the posttranslational modification of many proteins. The prenylation of small GTP-binding proteins such as Rho, Rac and Ras is involved in the pathophysiology of atherosclerosis; for example, the prenylation of Rho proteins down-regulates eNOS expression [66]. This posttranslational modification promotes membrane-protein-protein interactions and influences several intracellular signaling pathways [67,68]. Statins diminish the formation of isoprenylated and geranylgeranylated proteins. Thus, the statin-induced inhibition of isoprenoid formation on Rho proteins might increase eNOS expression. Caveolin is a scaffolding protein on lipid rafts in the plasma membrane that blocks eNOS access to its cofactor and substrate, resulting in reduced NO production, which is reversed by statins $[69,70]$. The beneficial effects of statins are also associated with less reactive oxygen species 
(ROS) being produced in the vasculature through inhibiting the activation of oxidant system NADPH oxidase [71,72]. The inhibition of Rac-1 prenylation appears to mediate the down-regulation of NADPH oxidase [73].

Ezetimibe is a novel lipid lowering agent, which unlike statins, selectively inhibits biliary and dietary cholesterol absorption from the small intestine. Increasing evidence has shown that this agent, when applied alone or in combination with statins, decreases LDL-C levels and the probability of cardiovascular events [74,75]. The following paragraph reviews the effects of ezetimibe on clinically detectable endothelial function.

\section{Clinical effect of ezetimibe on endothelial function}

Endothelial dysfunction is an early event in the pathogenesis of atherosclerosis, and it predicts cardiovascular complications in patients with coronary artery disease (CAD) [76,77]. Therefore, the assessment of vascular endothelial function is clinically important. Historically, endothelial-dependent vasomotion induced by the pharmacological or physiological stimulation of NO release from endothelial cells has been the most popular method of such assessment. For example, infusing the coronary arteries with acetylcholine can detect epicardial coronary arterial spasm, because it can dilate or constrict blood vessels with or without an intact endothelium, respectively [78-82]. However, this method is invasive and requires coronary angiography. Over the past decade, several new techniques have been developed to assess endothelium-dependent vascular function in the forearm arteries, among which, vasodilator responses in the brachial artery to an infusion of endothelium-dependent vasodilators such as acetylcholine measured by strain gauge plethysmography after venous occlusion is important [43]. Another is flow-mediated vasodilation (FMD) 
with high-resolution ultrasonography [83]. Forearm blood flow is influenced mainly by the endothelial function of resistant vessels, whereas FMD reflects mainly that of the conduit arteries [84]. Although these techniques are not significantly associated, endothelial-dependent vasodilation with either of them is related to endothelial function in coronary arteries [85,86]. Thus, these techniques allow the minimally- or non-invasive assessment of endothelial function in humans, and thus alter the morbidity or mortality of patients with atherosclerosis.

Several studies have examined whether ezetimibe has effects other than cholesterol-lowering or improves endothelial function measured as forearm vasodilator responses and/or FMD. Bulut et al. [87] showed that switching from atorvastatin 40 to $10 \mathrm{mg} /$ day combined with ezetimibe $10 \mathrm{mg} /$ day, induced a significant additional reduction in cholesterol and improved endothelial function in patients with metabolic syndrome. Olijhoek et al. [88] demonstrated that post-fat load FMD was preserved in patients with metabolic syndrome taking simvastatin and ezetimibe (both $10 \mathrm{mg} /$ day), findings that were contrary to those generated by $80 \mathrm{mg}$ of simvastatin. Settergren et al. [89] showed that FMD after 6 weeks increased from 4.3 to $5.5 \%$ in patients given simvastatin and ezetimibe (both $10 \mathrm{mg} /$ day) and from 4.3 to $5.2 \%$ in those given simvastatin ( $80 \mathrm{mg} / \mathrm{day})$. However, the increase in FMD between the groups did not significantly differ. These findings suggest that low-dose statin combined with ezetimibe is more (or similarly) effective on endothelial function than high-dose statin. In contrast, monotherapy with statin, but not ezetimibe, improves endothelial function in patients with congestive heart failure [90,91]. Moreover, low-dose statin plus ezetimibe was not superior to high-dose statin monotherapy in terms of improving peripheral endothelial function in patients with CAD $[92,93]$. The effects of ezetimibe 
on endothelial function measured as forearm vasodilator responses or FMD are summarized in Table 1.

Collectively, ezetimibe monotherapy is less effective than statin monotherapy in improving endothelial function, but the effect of combining ezetimibe with low-dose statin is greater than, or similar to that of high-dose statin. Ezetimibe might be more effective in the primary prevention of $\mathrm{CAD}$, such as in avoiding metabolic syndrome. Whether the effects of ezetimibe on endothelial function are dependent or independent of cholesterol-lowering remain unknown. However, that improvements in endothelial function are direct effects of ezetimibe on vascular endothelial cells is unlikely because only a little ezetimibe is absorbed into the blood circulation.

\section{Effect of ezetimibe on NO}

Ezetimibe, especially in combination with statin, might exert a favorable effect on endothelial function in the clinical setting. Ezetimibe might modulate the pathway of NO mediated by eNOS, which is a key factor in maintaining the integrity of the vascular endothelium. However, few reports have described an association between ezetimibe and NO.

One study using an animal model has shown that ezetimibe reduces plaque progression by 47 and $27 \%$ in male and female apoE knockout mice, respectively, and by 34 and $26 \%$ in male and female apoE/eNOS double-knockout mice, respectively, compared to animals of the same genotype fed with a western diet [94]. Furthermore, the same study showed that ezetimibe did not influence eNOS protein expression or NO production in blood vessels of apoE knockout mice. Thus, the anti-atherosclerotic effect of this agent seems largely eNOS independent, although the effects might be 
partially mediated by the eNOS pathway because plaque areas were more reduced among male apoE knockout, than in male apoE/eNOS double-knockout mice. On the other hand, the expression of vascular cell adhesion molecule-1 (VCAM-1) protein was significantly reduced in both genotypes. Thus, ezetimibe might reduce VCAM-1 expression dependently upon the LDL-C lowering effect, but not upon eNOS function, although the reduction of VCAM-1 expression by statins is considered to be dependent on the eNOS pathway [95].

Birnbaum et al. have demonstrated differential effects on myocardial infarction among high-dose statin, low-dose statin, ezetimibe and ezetimibe plus low-dose statin [96]. In rats orally pretreated with high-dose atorvastain and simvastatin (both 10 $\mathrm{mg} / \mathrm{kg} /$ day), the sizes of myocardial infarctions induced by ischemia-reperfusion injury were decreased whereas activity levels of calcium-dependent NOS including eNOS were significantly increased compared to sham treated rats. In contrast, infarction size was not reduced in rats pretreated with low-dose simvastatin $(2 \mathrm{mg} / \mathrm{kg} / \mathrm{day})$ alone, ezetimibe (1 mg/kg/day) alone or a combination of the two. Calcium-dependent NOS activity was reduced by low-dose monotherapy with either simvastatin or ezetimibe, and slightly increased by a combination of both. These findings suggest that ezetimibe alone or in combination with low-dose statin has no effect on the eNOS bioavailability that can protect against myocardial infarction in rats.

In contrast, Nakagami et al. [97] recently demonstrated that ezetimibe significantly reduced LDL-C levels in ApoE-deficient mice on a high-fat diet and up-regulated the expression of eNOS mRNA and protein. Furthermore, ezetimibe suppressed the expression of interleukin-6 (IL-6), an inflammatory cytokine, as well as oxidative stress assessed as dihydroethidium staining in the aorta. Ezetimibe 
eventually prevented the progression of lipid plaque and hepatic lipid accumulation. Lipid-lowering mediates these favorable effects of ezetimibe on atherosclerosis as well as direct and/or indirect vascular protective effects.

An association between ezetimibe with NO in humans has also been described. Asymmetric dimethylarginine (ADMA), an endogenous NO synthase inhibitor, is considered a novel emerging risk factor for cardiovascular disease in patients with chronic kidney disease $[98,99]$. Six months of ezetimibe significantly decreased ADMA levels independently of cholesterol in patients with early stage chronic kidney disease and dyslipidemia [100]. That study also showed that ezetimibe reduced urinary excretion levels of 8-hydroxy deoxyguanosine (8-OHdG), an oxidative stress marker. Thus, the mechanism of ADMA reduction might be mediated by its own anti-oxidative properties. Indeed, oxidative stress inactivates dimethylarginine dimethyl aminohydrolase, a rate-limiting enzyme of ADMA degradation, and increases ADMA levels [101]. These suggest that ezetimibe improves NOS activity through effects that are independent of cholesterol lowering. The effect of ezetimibe on NO requires more detailed investigation.

\section{Effect of ezetimibe on endothelial progenitor cells}

Interest in EPCs that purportedly function in maintenance of endothelial integrity, function and postnatal neovascularization is increasing [33]. Several studies have demonstrated that the number and function of EPCs are affected by cardiovascular risk factors such as dyslipidemia, hypertension, diabetes mellitus and smoking [34,102,103]. Levels of LDL-C negatively correlate with numbers of EPCs and impair their migration, proliferation, vasculogenic capacity and other properties [103,104]. Elevated 
cholesterol levels in sera decrease the number of colony forming units of EPCs [105]. Oxidation alters the native properties of LDL and scavenger receptors incorporate it into macrophages, through which it deteriorates various vascular wall functions such as the inhibition of endothelial nitric oxide (NO) production, endothelial apoptosis and the proliferation of smooth muscle cells [106]. Oxidized LDL (oxLDL) detrimentally affects the number and activity of EPCs, inhibits EPC differentiation and induces EPC senescence [107-109]. The mechanism of these effects involves a decrease in Akt phosphorylation and eNOS protein as well as in mRNA expression within EPCs [110]. Indeed, circulating levels of ADMA inversely correlate with the number of EPCs and down-regulate EPC function [111]. A lectin-like oxidized LDL receptor (LOX-1), identified predominantly in endothelial cells where it mediates the biological effects of oxLDL, is also involved in the mechanism through interaction with eNOS. Thus, eNOS-derived NO plays a key role in the mobilization and function of EPCs $[47,108]$.

Statins increase the numbers of circulating EPCs, inhibit their apoptosis and enhance their proliferation. These effects are considered to be mainly mediated by endothelial NO availability. Statins activate the phosphorylation of Akt, a serine-threonine kinase, through phosphatidylinositol 3-kinase (PI3K), leading to eNOS phosphorylation at serine 1177 [112,113]. Li et al. [114] recently demonstrated that lovastatin-enhanced EPC differentiation is mediated, at least in part, by AMP-activated protein kinase via eNOS phosphorylation. Furthermore, atorvastatin affects micro RNA (miR)-221/-222 expression, which might control the proliferation and differentiation of CD34-positive hematopoietic progenitor cells in EPCs and increase the number of EPCs via an eNOS-dependent pathway in patients with CAD [115]. 
A few investigators have examined the effects of ezetimibe on EPCs. Landmesser et al. [91] identified an obvious increase in the number of functionally active EPCs after 4 weeks of treatment with simvastatin, but not with ezetimibe. This suggests that ezetimibe alone does not exert a better effect on the number of EPCs compared to statin monotherapy. Westerweel et al. [42] showed that obese men with metabolic syndrome but without diabetes or manifest cardiovascular disease have lower levels of circulating EPCs than age-matched controls without metabolic syndrome. On the other hand, they found that the effects on EPC levels in this population were similar between low-dose simvastatin plus ezetimibe and high-dose simvastatin that achieve similar LDL-C levels. This suggests that LDL-C reduction is more important than the pleiotropic effects of statins. Thus, ezetimibe combined with a statin might result in a synergistic effect on EPC functions.

\section{Effect of ezetimibe on inflammation}

C-reactive protein (CRP), mainly produced by hepatocytes in response to IL-6 and then secreted into the systemic circulation, is an acute-phase reactant in humans [116]. Elevated CRP levels are related to impaired endothelial function and comprise a powerful predictor of future cardiovascular events. Furthermore, studies in vitro have shown that CRP modulates the activity and expression of several factors implicated in atherogenesis; for example CRP down-regulates eNOS and decreases NO release, which facilitates endothelial dysfunction [117].

Studies that have examined the effect of statin alone and a statin-ezetimibe combination on CRP are listed in Table 2. Pearson et al. [118] reported the effects of ezetimibe alone or in combination with statins on CRP and LDL-C determined from 
two pooled analyses of randomized, placebo-controlled trials in patients with hypercholesterolemia. The investigation included six studies of ezetimibe monotherapy and seven of ezetimibe added to ongoing statin therapy. Ezetimibe monotherapy induced a mean $1 \%$ decrease in CRP after 12 weeks; the mean difference from placebo was $6 \%(\mathrm{p}=0.09)$. In contrast, ezetimibe added to baseline statin resulted in a significant additional reduction in CRP (mean treatment difference was $10 \%, \mathrm{P}<0.001)$ after $6-8$ weeks. Thus, although adding ezetimibe to statin obviously enhances CRP reduction, the role of ezetimibe monotherapy is less well defined. Efrati et al. [119] reported that adding ezetimibe to $40 \mathrm{mg}$ of simvastatin reduced CRP to levels below that achieved by doubling the statin dose. However, ezetimibe combined with rosuvastatin significantly reduced CRP levels compared to rosuvastatin alone [120], whereas a single tablet comprising ezetimibe/simvastatin induced a greater reduction in LDL-C levels relative to rosuvastatin but a similar change in hs-CRP levels in both groups [121]. Although combination therapy seems to be superior to statin monotherapy in terms of lowering LDL-C, a superior effect on CRP remains contentious. Even studies that demonstrated a favorable effect of combination therapy on CRP also found a significantly larger reduction in LDL-C. Therefore, whether the effect of ezetimibe on CRP is dependent or independent of its cholesterol-lowering effect remains unknown. To understand the differences in CRP reduction among therapies that achieve similar levels of LDL reduction is important because clinicians may choose lipid-lowering therapy based not only on a reduction in LDL, but also in CRP.

Thus, ezetimibe might have synergistic effects on levels of CRP as well as of LDL-C when combined with statins, although whether the effect on CRP is dependent 
or independent of its cholesterol-lowering effect remains undetermined.

\section{Effect of ezetimibe on oxidative stress}

Oxidative stress caused by enhanced production of reactive oxygen species (ROS) and/or decreased antioxidant levels plays an important role in the pathophysiology of vascular endothelial dysfunction, resulting in abnormal vasorelaxation. Several reports describe the effect of ezetimibe on oxidative stress.

Animal studies have shown that ezetimibe suppresses ROS production in the aorta [97] and liver [122]. Ezetimibe monotherapy exerted the highest increase in the hepatic alpha-tocopherol/maleic dialdehyde ratio (means antioxidant/oxidant ratio), compared to monotherapy with other insulin-sensitizing agents, such as rosiglitazone, metoformin and valsartan in a methionine choline-deficient diet rat model of non-alcoholic fatty liver disease [123]. This suggests that ezetimibe has antioxidant

effects. Hussein et al. [124] demonstrated that three months of ezetimibe (10 $\mathrm{mg} /$ day) prolonged the lag time to LDL oxidation from $144 \pm 18$ to $195 \pm 16 \mathrm{~min}$, and that add-on simvastatin induced further prolongation of LDL oxidation and decreased the malondialdehyde content in LDL compared to simvastatin monotherapy in hypercholesterolemic patients. Ezetimibe for six months reduced urinary excretion levels of 8-OHdG as well as protein in patients with non-diabetic chronic kidney disease and dyslipidemia [100]. Ezetimibe significantly decreased the levels of oxidized LDL in patients with rheumatoid arthritis, although to a lesser extent than simvastatin [125]. In contrast, Landmesser at al. [91] demonstrated that the activity of endothelium-bound extracellular superoxide dismutase, a major antioxidant enzyme, released by a bolus injection of heparin is increased by simvastatin, but not by ezetimibe. A comparison 
of atorvastatin $(80 \mathrm{mg})$ and atorvastatin $(10 \mathrm{mg})+$ ezetimibe $(10 \mathrm{mg})$ in patients with CAD found no difference in levels of urinary 8-iso-prostaglandin F2 $\alpha$, a metabolite in the arachidonic cascade regarded as an oxidative stress marker in vivo [92]. These findings indicated that ezetimibe improves oxidative status in animal models. In contrast, the improvement by ezetimibe in humans remains controversial. It might be due to small number of subjects, and differences as well as stabilities of oxidative stress markers in the previous studies.

\section{Effect of ezetimibe on cardiovascular events in clinical trials}

Ezetimibe, especially in combination with statin, might ameliorate endothelial dysfunction. However, whether ezetimibe impacts morbidity and mortality in patients with cardiovascular diseases remains obscure. Two large, long-term trials of ezetimibe, in which the primary outcome was designated as a change in carotid intima-media thickness (CIMT), have recently been published: the Ezetimibe and Simvastatin in Hypercholesterolemia Enhances Atherosclerosis Regression (ENHANCE) [126] and Stop Atherosclerosis in Native Diabetics Study (SANDS) trials [127]. The former trial of 720 patients with heterozygous familial hypercholesterolemia found that simvastatin (80 $\mathrm{mg}$ ) combined with ezetimibe $(10 \mathrm{mg})$ for 24 months significantly reduced levels of LDL-C and hs-CRP compared to simvastatin $(80 \mathrm{mg})$ alone. However, CIMT changes did not differ between the two groups (simvastatin vs simvastatin+ezetimibe: +0.0033 vs $+0.00182 \mathrm{~mm} ; \mathrm{p}=0.15)$. This might mean that ezetimibe does not exert additional effects on CIMT progression. However, the results might be affected by various factors, such as the study subjects having a low level of CIMT at baseline and $81 \%$ of them taking statins before the study. The latter was a randomized, open-label, 3-year 
trial that examined the effects of aggressive goals for LDL-C $(\leq 70 \mathrm{mg} / \mathrm{dl})$, non-HDL-C $(\leq 100 \mathrm{mg} / \mathrm{dl})$ and blood pressure $(\leq 115 / 75 \mathrm{~mm} \mathrm{Hg})$ reduction versus standard goals of $\leq 100 \mathrm{mg} / \mathrm{dl}, \leq 130 \mathrm{mg} / \mathrm{dl}$ and $\leq 130 / 80 \mathrm{~mm} \mathrm{Hg}$, respectively, in 499 individuals with type 2 diabetes. In 223 patients in the aggressive treatment group, 69 required ezetimibe added to statin, and CIMT similarly regressed from baseline in both subgroups with or without ezetimibe $(-0.025 \mathrm{vs}-0.012 \mathrm{~mm}$, for subgroups with or without ezetimibe, respectively). On the other hand, CIMT progressed in the group that received standard treatment $(0.039 \mathrm{~mm})$. In addition, multivariate analysis revealed that changes in LDL-C levels, but not use of ezetimibe, independently correlated with changes in CIMT. These results indicate that aggressive cholesterol lowering therapy results in CIMT regression regardless of ezetimibe. However many patients required ezetimibe to achieve the aggressive goal. The Simvastatin and Ezetimibe in Aortic Stenosis (SEAS) study showed that simvastatin and ezetimibe neither inhibited the progression of aortic stenosis nor reduced major cardiovascular events in 1873 patients with asymptomatic, mild-to-moderate aortic stenosis during a median follow-up of 52.2 months [128]. Limited cohort studies have not yet shown additional and beneficial effects of ezetimibe on cardiovascular events in the clinical setting. Large cohort studies are required to examine the anti-atherosclerotic effects of ezetimibe in the setting of primary or secondary prevention.

\section{Conclusions}

Statin alone is currently insufficient for patients with hypercholesterolemia, especially those at high risk for cardiovascular disease, to achieve guideline-defined LDL-C goals. Ezetimibe is a potent LDL-C lowering agent, and, when combined with 
statins, it might induce synergistic effects not only lipid profiles but also on surrogate markers of future cardiovascular events, such as endothelial function, CRP and oxidative stress (Figure 1). The simultaneous inhibition of cholesterol synthesis by statin and of cholesterol absorption by ezetimibe might retard the atherogenetic process. These effects are considered to be mainly mediated by lipid lowering. However, further studies should elucidate the mechanism of the anti-atherosclerotic effects induced by ezetimibe; for instance, whether or not it directly affects atherogenesis independently from its lipid-lowering effects. 


\section{References}

1. Summary of the second report of the National Cholesterol Education Program (NCEP) Expert Panel on Detection, Evaluation, and Treatment of High Blood Cholesterol in Adults (Adult Treatment Panel II). Jama 1993, 269:3015-3023.

2. Executive Summary of The Third Report of The National Cholesterol Education Program (NCEP) Expert Panel on Detection, Evaluation, And Treatment of High Blood Cholesterol In Adults (Adult Treatment Panel III). Jama 2001, 285:2486-2497.

3. De Backer G, Ambrosioni E, Borch-Johnsen K, Brotons C, Cifkova R, Dallongeville J, et al.: European guidelines on cardiovascular disease prevention in clinical practice. Third Joint Task Force of European and Other Societies on Cardiovascular Disease Prevention in Clinical Practice. Eur Heart J 2003, 24:1601-1610.

4. Grundy SM, Cleeman JI, Merz CN, Brewer HB, Jr., Clark LT, Hunninghake DB, et al.: Implications of recent clinical trials for the National Cholesterol Education Program Adult Treatment Panel III guidelines. Circulation 2004, 110:227-239.

5. Andrews TC, Ballantyne CM, Hsia JA, Kramer JH: Achieving and maintaining National Cholesterol Education Program low-density lipoprotein cholesterol goals with five statins. Am J Med 2001, 111:185-191.

6. Pearson TA, Laurora I, Chu H, Kafonek S: The lipid treatment assessment project (L-TAP): a multicenter survey to evaluate the percentages of dyslipidemic patients receiving lipid-lowering therapy and achieving low-density lipoprotein cholesterol goals. Arch Intern Med 2000, 160:459-467.

7. Foley KA, Simpson RJ, Jr., Crouse JR, 3rd, Weiss TW, Markson LE, Alexander CM: Effectiveness of statin titration on low-density lipoprotein cholesterol goal attainment in patients at high risk of atherogenic events. Am J Cardiol 2003, 92:79-81. 
8. Dembowski E, Davidson MH: Statin and ezetimibe combination therapy in cardiovascular disease. Curr Opin Endocrinol Diabetes Obes 2009, 16:183-188.

9. Jones PH, Davidson MH, Stein EA, Bays HE, McKenney JM, Miller E, et al.: Comparison of the efficacy and safety of rosuvastatin versus atorvastatin, simvastatin, and pravastatin across doses (STELLAR* Trial). Am J Cardiol 2003, 92:152-160.

10. Dujovne CA, Ettinger MP, McNeer JF, Lipka LJ, LeBeaut AP, Suresh R, et al.: Efficacy and safety of a potent new selective cholesterol absorption inhibitor, ezetimibe, in patients with primary hypercholesterolemia. Am J Cardiol 2002, 90:1092-1097.

11. Knopp RH, Gitter H, Truitt T, Bays H, Manion CV, Lipka LJ, et al.: Effects of ezetimibe, a new cholesterol absorption inhibitor, on plasma lipids in patients with primary hypercholesterolemia. Eur Heart J 2003, 24:729-741.

12. Altmann SW, Davis HR, Jr., Zhu LJ, Yao X, Hoos LM, Tetzloff G, et al.: Niemann-Pick C1 Like 1 protein is critical for intestinal cholesterol absorption. Science 2004, 303:1201-1204.

13. Sudhop T, Lutjohann D, Kodal A, Igel M, Tribble DL, Shah S, et al.: Inhibition of intestinal cholesterol absorption by ezetimibe in humans. Circulation 2002, 106:1943-1948.

14. Ballantyne CM, Houri J, Notarbartolo A, Melani L, Lipka LJ, Suresh R, et al.: Effect of ezetimibe coadministered with atorvastatin in 628 patients with primary hypercholesterolemia: a prospective, randomized, double-blind trial. Circulation 2003, 107:2409-2415.

15. Genest J: Combination of statin and ezetimibe for the treatment of dyslipidemias and the prevention of coronary artery disease. Can J Cardiol 2006, 22:863-868. 
16. Gagne C, Bays HE, Weiss SR, Mata P, Quinto K, Melino M, et al.: Efficacy and safety of ezetimibe added to ongoing statin therapy for treatment of patients with primary hypercholesterolemia. Am J Cardiol 2002, 90:1084-1091.

17. Vita JA, Keaney JF, Jr.: Endothelial function: a barometer for cardiovascular risk? Circulation 2002, 106:640-642.

18. Ross R: The pathogenesis of atherosclerosis: a perspective for the 1990s. Nature 1993, 362:801-809.

19. Schechter AN, Gladwin MT: Hemoglobin and the paracrine and endocrine functions of nitric oxide. $N$ Engl J Med 2003, 348:1483-1485.

20. Furchgott RF, Zawadzki JV: The obligatory role of endothelial cells in the relaxation of arterial smooth muscle by acetylcholine. Nature 1980, 288:373-376.

21. Forstermann U, Munzel T: Endothelial nitric oxide synthase in vascular disease: from marvel to menace. Circulation 2006, 113:1708-1714.

22. Govers R, Rabelink TJ: Cellular regulation of endothelial nitric oxide synthase. Am J Physiol Renal Physiol 2001, 280:F193-206.

23. Bonetti PO, Lerman LO, Lerman A: Endothelial dysfunction: a marker of atherosclerotic risk. Arterioscler Thromb Vasc Biol 2003, 23:168-175.

24. Gonzalez MA, Selwyn AP: Endothelial function, inflammation, and prognosis in cardiovascular disease. Am J Med 2003, 115 Suppl 8A:99S-106S.

25. Grover-Paez F, Zavalza-Gomez AB: Endothelial dysfunction and cardiovascular risk factors. Diabetes Res Clin Pract 2009, 84:1-10.

26. Moncada S: Nitric oxide in the vasculature: physiology and pathophysiology. Ann $N$ Y Acad Sci 1997, 811:60-67; discussion 67-69.

27. Marletta MA: Nitric oxide: biosynthesis and biological significance. Trends Biochem 
Sci 1989, 14:488-492.

28. Li H, Wallerath T, Munzel T, Forstermann U: Regulation of endothelial-type NO synthase expression in pathophysiology and in response to drugs. Nitric Oxide 2002, $7: 149-164$

29. Feron O, Balligand JL: Caveolins and the regulation of endothelial nitric oxide synthase in the heart. Cardiovasc Res 2006, 69:788-797.

30. Vanhoutte PM: Endothelial dysfunction: the first step toward coronary arteriosclerosis. Circ J 2009, 73:595-601.

31. Caplan BA, Schwartz CJ: Increased endothelial cell turnover in areas of in vivo Evans Blue uptake in the pig aorta. Atherosclerosis 1973, 17:401-417.

32. Dimmeler S, Zeiher AM: Vascular repair by circulating endothelial progenitor cells: the missing link in atherosclerosis? J Mol Med 2004, 82:671-677.

33. Rafii S, Lyden D: Therapeutic stem and progenitor cell transplantation for organ vascularization and regeneration. Nat Med 2003, 9:702-712.

34. Shantsila E, Watson T, Lip GY: Endothelial progenitor cells in cardiovascular disorders. J Am Coll Cardiol 2007, 49:741-752.

35. Fadini GP, Agostini C, Avogaro A: Characterization of endothelial progenitor cells. Biochem Biophys Res Commun 2005, 336:1-2.

36. Khakoo AY, Finkel T: Endothelial progenitor cells. Annu Rev Med 2005, 56:79-101.

37. Asahara T, Murohara T, Sullivan A, Silver M, van der Zee R, Li T, et al.: Isolation of putative progenitor endothelial cells for angiogenesis. Science 1997, 275:964-967.

38. Hristov M, Erl W, Weber PC: Endothelial progenitor cells: mobilization, differentiation, and homing. Arterioscler Thromb Vasc Biol 2003, 23:1185-1189.

39. Mohler ER, 3rd, Shi Y, Moore J, Bantly A, Hamamdzic D, Yoder M, et al.: Diabetes 
reduces bone marrow and circulating porcine endothelial progenitor cells, an effect ameliorated by atorvastatin and independent of cholesterol. Cytometry A 2009, $75: 75-82$

40. Aicher A, Heeschen C, Mildner-Rihm C, Urbich C, Ihling C, Technau-Ihling K, et al.: Essential role of endothelial nitric oxide synthase for mobilization of stem and progenitor cells. Nat Med 2003, 9:1370-1376.

41. Aicher A, Heeschen C, Dimmeler S: The role of NOS3 in stem cell mobilization. Trends Mol Med 2004, 10:421-425.

42. Westerweel PE, Visseren FL, Hajer GR, Olijhoek JK, Hoefer IE, de Bree P, et al.: Endothelial progenitor cell levels in obese men with the metabolic syndrome and the effect of simvastatin monotherapy vs. simvastatin/ezetimibe combination therapy. Eur Heart J 2008, 29:2808-2817.

43. Anderson TJ: Assessment and treatment of endothelial dysfunction in humans. $J$ Am Coll Cardiol 1999, 34:631-638.

44. Laursen JB, Somers M, Kurz S, McCann L, Warnholtz A, Freeman BA, et al.: Endothelial regulation of vasomotion in apoE-deficient mice: implications for interactions between peroxynitrite and tetrahydrobiopterin. Circulation 2001, $103: 1282-1288$.

45. Alp NJ, Channon KM: Regulation of endothelial nitric oxide synthase by tetrahydrobiopterin in vascular disease. Arterioscler Thromb Vasc Biol 2004, $24: 413-420$

46. O'Brien SF, Watts GF, Playford DA, Burke V, O'Neal DN, Best JD: Low-density lipoprotein size, high-density lipoprotein concentration, and endothelial dysfunction in non-insulin-dependent diabetes. Diabet Med 1997, 14:974-978. 
47. Ma FX, Zhou B, Chen Z, Ren Q, Lu SH, Sawamura T, et al.: Oxidized low density lipoprotein impairs endothelial progenitor cells by regulation of endothelial nitric oxide synthase. J Lipid Res 2006, 47:1227-1237.

48. Hedblad B, Ogren M, Janzon L, Isacsson SO, Lindell SE: Low pulse-wave amplitude during reactive leg hyperaemia: an independent, early marker for ischaemic heart disease and death. Results from the 21-year follow-up of the prospective cohort study 'Men born in 1914', Malmo, Sweden. J Intern Med 1994, 236:161-168.

49. Perticone F, Ceravolo R, Pujia A, Ventura G, Iacopino S, Scozzafava A, et al.: Prognostic significance of endothelial dysfunction in hypertensive patients. Circulation 2001, 104:191-196.

50. Heitzer T, Schlinzig T, Krohn K, Meinertz T, Munzel T: Endothelial dysfunction, oxidative stress, and risk of cardiovascular events in patients with coronary artery disease. Circulation 2001, 104:2673-2678.

51. Gokce N, Keaney JF, Jr., Hunter LM, Watkins MT, Menzoian JO, Vita JA: Risk stratification for postoperative cardiovascular events via noninvasive assessment of endothelial function: a prospective study. Circulation 2002, 105:1567-1572.

52. Vogel RA: Cholesterol lowering and endothelial function. Am J Med 1999, 107:479-487.

53. Taddei S, Virdis A, Ghiadoni L, Sudano I, Salvetti A: Effects of antihypertensive drugs on endothelial dysfunction: clinical implications. Drugs 2002, 62:265-284.

54. Celermajer DS, Sorensen KE, Georgakopoulos D, Bull C, Thomas O, Robinson J, et al.: Cigarette smoking is associated with dose-related and potentially reversible impairment of endothelium-dependent dilation in healthy young adults. Circulation $1993,88: 2149-2155$. 
55. Hambrecht R, Wolf A, Gielen S, Linke A, Hofer J, Erbs S, et al.: Effect of exercise on coronary endothelial function in patients with coronary artery disease. $N$ Engl $J$ Med 2000, 342:454-460.

56. Vita JA, Keaney JF, Jr.: Hormone replacement therapy and endothelial function: the exception that proves the rule? Arterioscler Thromb Vasc Biol 2001, 21:1867-1869.

57. Libby P, Ridker PM, Maseri A: Inflammation and atherosclerosis. Circulation 2002, $105: 1135-1143$.

58. Murohara T, Kugiyama K, Ohgushi M, Sugiyama S, Ohta Y, Yasue H: LPC in oxidized LDL elicits vasocontraction and inhibits endothelium- dependent relaxation. Am J Physiol 1994, 267:H2441-2449.

59. Ohgushi M, Kugiyama K, Fukunaga K, Murohara T, Sugiyama S, Miyamoto E, et al.: Protein kinase $\mathrm{C}$ inhibitors prevent impairment of endothelium-dependent relaxation by oxidatively modified LDL. Arterioscler Thromb 1993, 13:1525-1532.

60. Tamai O, Matsuoka H, Itabe H, Wada Y, Kohno K, Imaizumi T: Single LDL apheresis improves endothelium-dependent vasodilatation in hypercholesterolemic humans. Circulation 1997, 95:76-82.

61. Arnaud C, Mach F: Pleiotropic effects of statins in atherosclerosis: role on endothelial function, inflammation and immunomodulation. Arch Mal Coeur Vaiss 2005, 98:661-666.

62. Calabro P, Yeh ET: The pleiotropic effects of statins. Curr Opin Cardiol 2005, 20:541-546.

63. Lahera V, Goicoechea M, de Vinuesa SG, Miana M, de las Heras N, Cachofeiro V, et al.: Endothelial dysfunction, oxidative stress and inflammation in atherosclerosis: beneficial effects of statins. Curr Med Chem 2007, 14:243-248. 
64. Athyros VG, Kakafika AI, Tziomalos K, Karagiannis A, Mikhailidis DP: Pleiotropic effects of statins--clinical evidence. Curr Pharm Des 2009, 15:479-489.

65. Ridker PM, Danielson E, Fonseca FA, Genest J, Gotto AM, Jr., Kastelein JJ, et al.: Rosuvastatin to prevent vascular events in men and women with elevated C-reactive protein. $N$ Engl J Med 2008, 359:2195-2207.

66. Goldstein JL, Brown MS: Regulation of the mevalonate pathway. Nature 1990, $343: 425-430$

67. Zhang FL, Casey PJ: Protein prenylation: molecular mechanisms and functional consequences. Annu Rev Biochem 1996, 65:241-269.

68. Casey PJ: Protein lipidation in cell signaling. Science 1995, 268:221-225.

69. Ju H, Zou R, Venema VJ, Venema RC: Direct interaction of endothelial nitric-oxide synthase and caveolin-1 inhibits synthase activity. J Biol Chem 1997, 272:18522-18525.

70. Mason RP, Walter MF, Jacob RF: Effects of HMG-CoA reductase inhibitors on endothelial function: role of microdomains and oxidative stress. Circulation 2004, 109:II34-41.

71. Haendeler J, Hoffmann J, Zeiher AM, Dimmeler S: Antioxidant effects of statins via S-nitrosylation and activation of thioredoxin in endothelial cells: a novel vasculoprotective function of statins. Circulation 2004, 110:856-861.

72. Maack C, Kartes T, Kilter H, Schafers HJ, Nickenig G, Bohm M, et al.: Oxygen free radical release in human failing myocardium is associated with increased activity of rac1-GTPase and represents a target for statin treatment. Circulation 2003, 108:1567-1574.

73. Wassmann S, Laufs U, Baumer AT, Muller K, Konkol C, Sauer H, et al.: Inhibition of 
geranylgeranylation reduces angiotensin II-mediated free radical production in vascular smooth muscle cells: involvement of angiotensin AT1 receptor expression and Rac1 GTPase. Mol Pharmacol 2001, 59:646-654.

74. Bays HE, Neff D, Tomassini JE, Tershakovec AM: Ezetimibe: cholesterol lowering and beyond. Expert Rev Cardiovasc Ther 2008, 6:447-470.

75. Al Badarin FJ, Kullo IJ, Kopecky SL, Thomas RJ: Impact of ezetimibe on atherosclerosis: is the jury still out? Mayo Clin Proc 2009, 84:353-361.

76. Schachinger V, Britten MB, Zeiher AM: Prognostic impact of coronary vasodilator dysfunction on adverse long-term outcome of coronary heart disease. Circulation 2000, 101:1899-1906.

77. Suwaidi JA, Hamasaki S, Higano ST, Nishimura RA, Holmes DR, Jr., Lerman A: Long-term follow-up of patients with mild coronary artery disease and endothelial dysfunction. Circulation 2000, 101:948-954.

78. Ludmer PL, Selwyn AP, Shook TL, Wayne RR, Mudge GH, Alexander RW, et al.: Paradoxical vasoconstriction induced by acetylcholine in atherosclerotic coronary arteries. $N$ Engl J Med 1986, 315:1046-1051.

79. Furchgott RF: Role of endothelium in responses of vascular smooth muscle. Circ Res 1983, 53:557-573.

80. Vanhoutte PM, Rimele TJ: Role of the endothelium in the control of vascular smooth muscle function. J Physiol (Paris) 1982, 78:681-686.

81. Werns SW, Walton JA, Hsia HH, Nabel EG, Sanz ML, Pitt B: Evidence of endothelial dysfunction in angiographically normal coronary arteries of patients with coronary artery disease. Circulation 1989, 79:287-291.

82. Horio Y, Yasue H, Rokutanda M, Nakamura N, Ogawa H, Takaoka K, et al.: Effects 
of intracoronary injection of acetylcholine on coronary arterial diameter. Am J Cardiol 1986, 57:984-989.

83. Deanfield J, Donald A, Ferri C, Giannattasio C, Halcox J, Halligan S, et al.: Endothelial function and dysfunction. Part I: Methodological issues for assessment in the different vascular beds: a statement by the Working Group on Endothelin and Endothelial Factors of the European Society of Hypertension. J Hypertens 2005, 23:7-17.

84. Wu HD, Katz SD, Beniaminovitz A, Khan T, DiTullio MR, Homma S: Assessment of endothelium-mediated vasodilation of the peripheral circulation by transcutaneous ultrasonography and venous occlusion plethysmography. Heart Vessels 1999, $14: 143-148$

85. Lerman A, Zeiher AM: Endothelial function: cardiac events. Circulation 2005, 111:363-368.

86. Lind L, Fors N, Hall J, Marttala K, Stenborg A: A comparison of three different methods to evaluate endothelium-dependent vasodilation in the elderly: the Prospective Investigation of the Vasculature in Uppsala Seniors (PIVUS) study. Arterioscler Thromb Vasc Biol 2005, 25:2368-2375.

87. Bulut D, Hanefeld C, Bulut-Streich N, Graf C, Mugge A, Spiecker M: Endothelial function in the forearm circulation of patients with the metabolic syndrome--effect of different lipid-lowering regimens. Cardiology 2005, 104:176-180.

88. Olijhoek JK, Hajer GR, van der Graaf Y, Dallinga-Thie GM, Visseren FL: The effects of low-dose simvastatin and ezetimibe compared to high-dose simvastatin alone on post-fat load endothelial function in patients with metabolic syndrome: a randomized double-blind crossover trial. J Cardiovasc Pharmacol 2008, 52:145-150. 
89. Settergren M, Bohm F, Ryden L, Pernow J: Cholesterol lowering is more important than pleiotropic effects of statins for endothelial function in patients with dysglycaemia and coronary artery disease. Eur Heart J 2008, 29:1753-1760.

90. Gounari P, Tousoulis D, Antoniades C, Kampoli AM, Stougiannos P, Papageorgiou N, et al.: Rosuvastatin but not ezetimibe improves endothelial function in patients with heart failure, by mechanisms independent of lipid lowering. Int J Cardiol 2009.

91. Landmesser U, Bahlmann F, Mueller M, Spiekermann S, Kirchhoff N, Schulz S, et al.: Simvastatin versus ezetimibe: pleiotropic and lipid-lowering effects on endothelial function in humans. Circulation 2005, 111:2356-2363.

92. Ostad MA, Eggeling S, Tschentscher P, Schwedhelm E, Boger R, Wenzel P, et al.: Flow-mediated dilation in patients with coronary artery disease is enhanced by high dose atorvastatin compared to combined low dose atorvastatin and ezetimibe: results of the CEZAR study. Atherosclerosis 2009, 205:227-232.

93. Fichtlscherer S, Schmidt-Lucke C, Bojunga S, Rossig L, Heeschen C, Dimmeler S, et al.: Differential effects of short-term lipid lowering with ezetimibe and statins on endothelial function in patients with CAD: clinical evidence for 'pleiotropic' functions of statin therapy. Eur Heart J 2006, 27:1182-1190.

94. Kuhlencordt PJ, Padmapriya P, Rutzel S, Schodel J, Hu K, Schafer A, et al.: Ezetimibe potently reduces vascular inflammation and arteriosclerosis in eNOS-deficient ApoE ko mice. Atherosclerosis 2009, 202:48-57.

95. Tsunekawa T, Hayashi T, Kano H, Sumi D, Matsui-Hirai H, Thakur NK, et al.: Cerivastatin, a hydroxymethylglutaryl coenzyme a reductase inhibitor, improves endothelial function in elderly diabetic patients within 3 days. Circulation 2001, 104:376-379. 
96. Birnbaum Y, Lin Y, Ye Y, Merla R, Perez-Polo JR, Uretsky BF: Pretreatment with high-dose statin, but not low-dose statin, ezetimibe, or the combination of low-dose statin and ezetimibe, limits infarct size in the rat. J Cardiovasc Pharmacol Ther 2008, $13: 72-79$.

97. Nakagami H, Osako MK, Takami Y, Hanayama R, Koriyama H, Mori M, et al.: Vascular protective effects of ezetimibe in ApoE-deficient mice. Atherosclerosis 2009, 203:51-58.

98. Vallance $\mathrm{P}$, Leiper $\mathrm{J}$ : Cardiovascular biology of the asymmetric dimethylarginine:dimethylarginine dimethylaminohydrolase pathway. Arterioscler Thromb Vasc Biol 2004, 24:1023-1030.

99. Ueda S, Yamagishi S, Matsumoto Y, Fukami K, Okuda S: Asymmetric dimethylarginine (ADMA) is a novel emerging risk factor for cardiovascular disease and the development of renal injury in chronic kidney disease. Clin Exp Nephrol 2007, $11: 115-121$

100. Nakamura T, Sato E, Fujiwara N, Kawagoe Y, Ueda Y, Suzuki T, et al.: Ezetimibe decreases serum levels of asymmetric dimethylarginine (ADMA) and ameliorates renal injury in non-diabetic chronic kidney disease patients in a cholesterol-independent manner. Pharmacol Res 2009.

101. Lin KY, Ito A, Asagami T, Tsao PS, Adimoolam S, Kimoto M, et al.: Impaired nitric oxide synthase pathway in diabetes mellitus: role of asymmetric dimethylarginine and dimethylarginine dimethylaminohydrolase. Circulation 2002, 106:987-992.

102. Edelberg JM, Tang L, Hattori K, Lyden D, Rafii S: Young adult bone marrow-derived endothelial precursor cells restore aging-impaired cardiac angiogenic function. Circ Res 2002, 90:E89-93. 
103. Vasa M, Fichtlscherer S, Aicher A, Adler K, Urbich C, Martin H, et al.: Number and migratory activity of circulating endothelial progenitor cells inversely correlate with risk factors for coronary artery disease. Circ Res 2001, 89:E1-7.

104. Chen JZ, Zhang FR, Tao QM, Wang XX, Zhu JH: Number and activity of endothelial progenitor cells from peripheral blood in patients with hypercholesterolaemia. Clin Sci (Lond) 2004, 107:273-280.

105. Hill JM, Zalos G, Halcox JP, Schenke WH, Waclawiw MA, Quyyumi AA, et al.: Circulating endothelial progenitor cells, vascular function, and cardiovascular risk. $N$ Engl J Med 2003, 348:593-600.

106. Steinberg D: Low density lipoprotein oxidation and its pathobiological significance. J Biol Chem 1997, 272:20963-20966.

107. Imanishi T, Hano T, Matsuo Y, Nishio I: Oxidized low-density lipoprotein inhibits vascular endothelial growth factor-induced endothelial progenitor cell differentiation. Clin Exp Pharmacol Physiol 2003, 30:665-670.

108. Imanishi T, Hano T, Sawamura T, Nishio I: Oxidized low-density lipoprotein induces endothelial progenitor cell senescence, leading to cellular dysfunction. Clin Exp Pharmacol Physiol 2004, 31:407-413.

109. Wang X, Chen J, Tao Q, Zhu J, Shang Y: Effects of ox-LDL on number and activity of circulating endothelial progenitor cells. Drug Chem Toxicol 2004, 27:243-255.

110. Fulton D, Gratton JP, McCabe TJ, Fontana J, Fujio Y, Walsh K, et al.: Regulation of endothelium-derived nitric oxide production by the protein kinase Akt. Nature 1999, 399:597-601.

111. Thum T, Tsikas D, Stein S, Schultheiss M, Eigenthaler M, Anker SD, et al.: Suppression of endothelial progenitor cells in human coronary artery disease by the 
endogenous nitric oxide synthase inhibitor asymmetric dimethylarginine. J Am Coll Cardiol 2005, 46:1693-1701.

112. Llevadot J, Murasawa S, Kureishi Y, Uchida S, Masuda H, Kawamoto A, et al.: HMG-CoA reductase inhibitor mobilizes bone marrow--derived endothelial progenitor cells. J Clin Invest 2001, 108:399-405.

113. Dimmeler S, Aicher A, Vasa M, Mildner-Rihm C, Adler K, Tiemann M, et al.: HMG-CoA reductase inhibitors (statins) increase endothelial progenitor cells via the PI 3-kinase/Akt pathway. J Clin Invest 2001, 108:391-397.

114. Li X, Han Y, Pang W, Li C, Xie X, Shyy JY, et al.: AMP-activated protein kinase promotes the differentiation of endothelial progenitor cells. Arterioscler Thromb Vasc Biol 2008, 28:1789-1795.

115. Minami Y, Satoh M, Maesawa C, Takahashi Y, Tabuchi T, Itoh T, et al.: Effect of atorvastatin on microRNA $221 / 222$ expression in endothelial progenitor cells obtained from patients with coronary artery disease. Eur J Clin Invest 2009, $39: 359-367$.

116. Rattazzi M, Puato M, Faggin E, Bertipaglia B, Zambon A, Pauletto P: C-reactive protein and interleukin-6 in vascular disease: culprits or passive bystanders? $J$ Hypertens 2003, 21:1787-1803.

117. Venugopal SK, Devaraj S, Yuhanna I, Shaul P, Jialal I: Demonstration that C-reactive protein decreases eNOS expression and bioactivity in human aortic endothelial cells. Circulation 2002, 106:1439-1441.

118. Pearson TA, Ballantyne CM, Veltri E, Shah A, Bird S, Lin J, et al.: Pooled analyses of effects on C-reactive protein and low density lipoprotein cholesterol in placebo-controlled trials of ezetimibe monotherapy or ezetimibe added to baseline 
statin therapy. Am J Cardiol 2009, 103:369-374.

119. Efrati S, Averbukh M, Dishy V, Faygenzo M, Friedensohn L, Golik A: The effect of simvastatin, ezetimibe and their combination on the lipid profile, arterial stiffness and inflammatory markers. Eur J Clin Pharmacol 2007, 63:113-121.

120. Ballantyne CM, Weiss R, Moccetti T, Vogt A, Eber B, Sosef F, et al.: Efficacy and safety of rosuvastatin $40 \mathrm{mg}$ alone or in combination with ezetimibe in patients at high risk of cardiovascular disease (results from the EXPLORER study). Am J Cardiol 2007, 99:673-680.

121. Catapano AL, Davidson MH, Ballantyne CM, Brady WE, Gazzara RA, Tomassini JE, et al.: Lipid-altering efficacy of the ezetimibe/simvastatin single tablet versus rosuvastatin in hypercholesterolemic patients. Curr Med Res Opin 2006, 22:2041-2053.

122. Nomura M, Ishii H, Kawakami A, Yoshida M: Inhibition of Hepatic Neiman-Pick C1-Like 1 Improves Hepatic Insulin Resistance. Am J Physiol Endocrinol Metab 2009.

123. Assy N, Grozovski M, Bersudsky I, Szvalb S, Hussein O: Effect of insulin-sensitizing agents in combination with ezetimibe, and valsartan in rats with non-alcoholic fatty liver disease. World J Gastroenterol 2006, 12:4369-4376.

124. Hussein O, Minasian L, Itzkovich Y, Shestatski K, Solomon L, Zidan J: Ezetimibe's effect on platelet aggregation and LDL tendency to peroxidation in hypercholesterolaemia as monotherapy or in addition to simvastatin. $\mathrm{Br} \mathrm{J}$ Clin Pharmacol 2008, 65:637-645.

125. Maki-Petaja KM, Booth AD, Hall FC, Wallace SM, Brown J, McEniery CM, et al.: Ezetimibe and simvastatin reduce inflammation, disease activity, and aortic stiffness 
and improve endothelial function in rheumatoid arthritis. J Am Coll Cardiol 2007, $50: 852-858$.

126. Kastelein JJ, Akdim F, Stroes ES, Zwinderman AH, Bots ML, Stalenhoef AF, et al.: Simvastatin with or without ezetimibe in familial hypercholesterolemia. $N$ Engl $J$ Med 2008, 358:1431-1443

127. Fleg JL, Mete M, Howard BV, Umans JG, Roman MJ, Ratner RE, et al.: Effect of statins alone versus statins plus ezetimibe on carotid atherosclerosis in type 2 diabetes: the SANDS (Stop Atherosclerosis in Native Diabetics Study) trial. J Am Coll Cardiol 2008, 52:2198-2205.

128. Rossebo AB, Pedersen TR, Boman K, Brudi P, Chambers JB, Egstrup K, et al.: Intensive lipid lowering with simvastatin and ezetimibe in aortic stenosis. $N$ Engl $J$ Med 2008, 359:1343-1356.

129. Malmstrom RE, Settergren M, Bohm F, Pernow J, Hjemdahl P: No effect of lipid lowering on platelet activity in patients with coronary artery disease and type 2 diabetes or impaired glucose tolerance. Thromb Haemost 2009, 101:157-164.

130. Alvarez-Sala LA, Cachofeiro V, Masana L, Suarez C, Pinilla B, Plana N, et al.: Effects of fluvastatin extended-release $(80 \mathrm{mg})$ alone and in combination with ezetimibe (10 $\mathrm{mg})$ on low-density lipoprotein cholesterol and inflammatory parameters in patients with primary hypercholesterolemia: A 12-week, multicenter, randomized, open-label, parallel-group study. Clin Ther 2008, 30:84-97.

131. Ballantyne CM, Abate N, Yuan Z, King TR, Palmisano J: Dose-comparison study of the combination of ezetimibe and simvastatin (Vytorin) versus atorvastatin in patients with hypercholesterolemia: the Vytorin Versus Atorvastatin (VYVA) study. Am Heart J 2005, 149:464-473. 
132. Robinson JG, Ballantyne CM, Grundy SM, Hsueh WA, Parving HH, Rosen JB, et al.: Lipid-altering efficacy and safety of ezetimibe/simvastatin versus atorvastatin in patients with hypercholesterolemia and the metabolic syndrome (from the VYMET study). Am J Cardiol 2009, 103:1694-1702.

133. Leiter LA, Bays H, Conard S, Bird S, Rubino J, Hanson ME, et al.: Efficacy and safety of ezetimibe added on to atorvastatin $(40 \mathrm{mg})$ compared with uptitration of atorvastatin (to $80 \mathrm{mg}$ ) in hypercholesterolemic patients at high risk of coronary heart disease. Am J Cardiol 2008, 102:1495-1501.

134. Conard SE, Bays HE, Leiter LA, Bird SR, Rubino J, Lowe RS, et al.: Efficacy and safety of ezetimibe added on to atorvastatin $(20 \mathrm{mg})$ versus uptitration of atorvastatin (to $40 \mathrm{mg}$ ) in hypercholesterolemic patients at moderately high risk for coronary heart disease. Am J Cardiol 2008, 102:1489-1494.

135. Sager PT, Capece R, Lipka L, Strony J, Yang B, Suresh R, et al.: Effects of ezetimibe coadministered with simvastatin on C-reactive protein in a large cohort of hypercholesterolemic patients. Atherosclerosis 2005, 179:361-367.

136. Goldberg AC, Sapre A, Liu J, Capece R, Mitchel YB: Efficacy and safety of ezetimibe coadministered with simvastatin in patients with primary hypercholesterolemia: a randomized, double-blind, placebo-controlled trial. Mayo Clin Proc 2004, 79:620-629.

137. Bays HE, Ose L, Fraser N, Tribble DL, Quinto K, Reyes R, et al.: A multicenter, randomized, double-blind, placebo-controlled, factorial design study to evaluate the lipid-altering efficacy and safety profile of the ezetimibe/simvastatin tablet compared with ezetimibe and simvastatin monotherapy in patients with primary hypercholesterolemia. Clin Ther 2004, 26:1758-1773. 


\section{Figure legends}

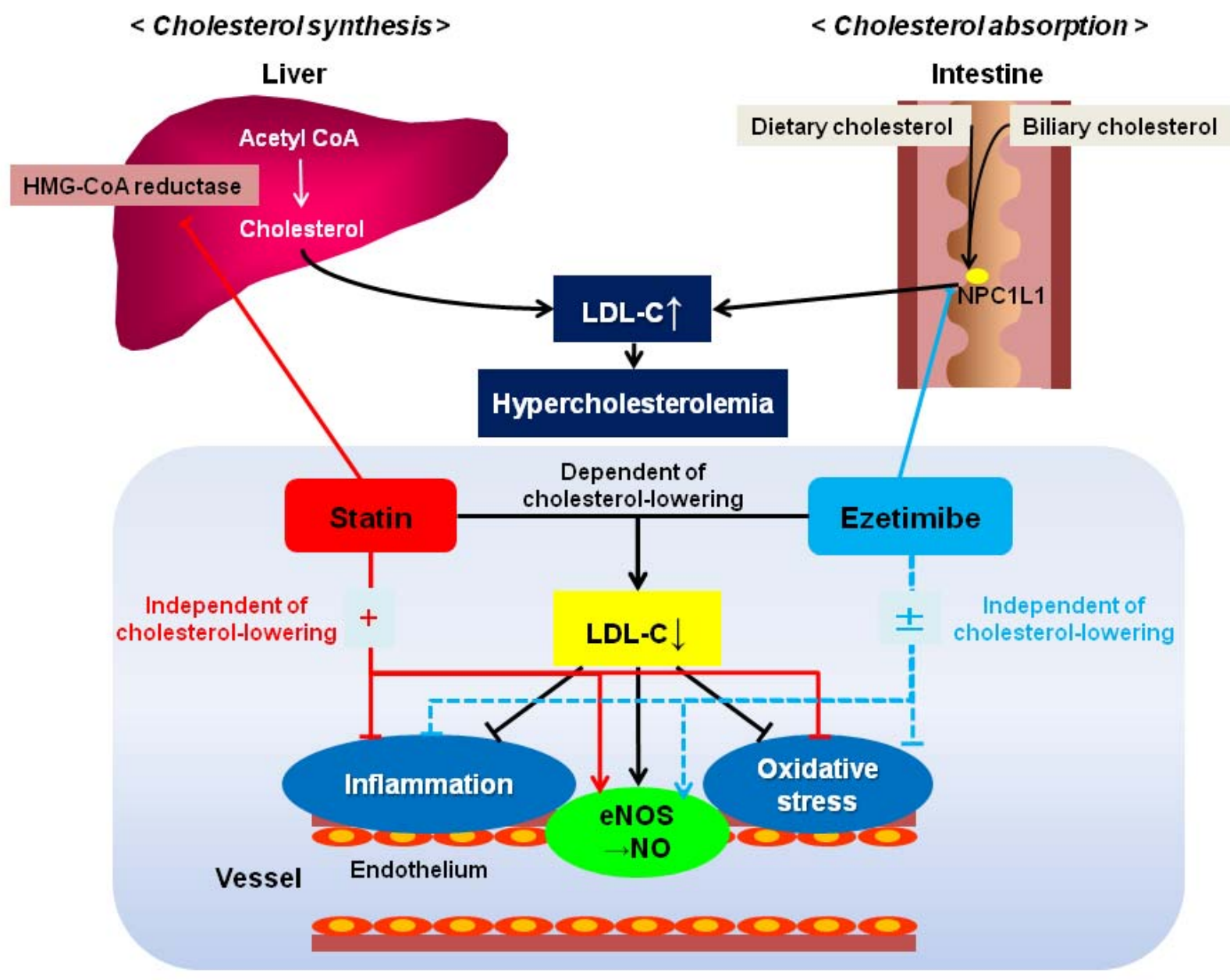

Figure 1. Effects of ezetimibe on vascular endothelium.

Elevated low-density lipoprotein cholesterol (LDL-C) induces impaired eNOS (endothelial nitric oxide synthase)-derived NO availability, inflammation and oxidative stress, leading to vascular endothelial dysfunction. Inhibition of cholesterol synthesis using statins and of cholesterol absorption using ezetimibe agents improves these effects in endothelial cells. 
Table 1. Effects of ezetimibe on clinical evaluation of endothelial function.

\begin{tabular}{|c|c|c|c|c|c|}
\hline Trial & Methods & Population & $\begin{array}{l}\text { Demographics } \\
\text { (Age, \%male) }\end{array}$ & $\begin{array}{c}\text { Intervention } \\
\text { (Medicines, Period) }\end{array}$ & Findings and conclusions \\
\hline Bulut et al. [87] & $\begin{array}{l}\text { Switch } \\
\text { FBF }\end{array}$ & $\begin{array}{l}14 \text { patients } \\
\text { with Mets }\end{array}$ & $\begin{array}{c}62.4 \pm 10.7 \text { years } \\
\text { Male: } 100 \%\end{array}$ & $\begin{array}{c}\text { Atorvastatin } 40 \mathrm{mg} / \mathrm{day} ;>4 \text { weeks } \\
\downarrow \\
\text { Atorvastatin } 10 \mathrm{mg} / \text { day }+ \text { ezetimibe } 10 \mathrm{mg} / \text { day } \\
8 \text { weeks }\end{array}$ & $\begin{array}{l}\text { Switching from atorvastatin } \\
\text { monothrapy to atorvastatin and } \\
\text { ezetimibe enhanced the increase } \\
\text { of FBF. }\end{array}$ \\
\hline Olijhoek et al. [88] & $\begin{array}{l}\mathrm{R}, \mathrm{DB} \\
\mathrm{CO} \\
\mathrm{FMD}\end{array}$ & $\begin{array}{l}19 \text { patients } \\
\text { with Mets }\end{array}$ & $\begin{array}{l}54 \pm 7 \text { years } \\
\text { Male: } 100 \%\end{array}$ & $\begin{array}{c}\text { Simvastatin } 80 \mathrm{mg} / \text { day } \\
\text { Simvastatin } 10 \mathrm{mg} / \text { day }+ \text { ezetimibe } 10 \mathrm{mg} / \text { day } \\
6 \text { weeks each arm }\end{array}$ & $\begin{array}{l}\text { The combination of simvastatin } \\
\text { and ezetimibe did not decrease } \\
\text { post-fat load FMD, contrary to } \\
\text { simvastatin monotherapy. }\end{array}$ \\
\hline Gounari et al. [90] & $\begin{array}{l}\mathrm{R}, \mathrm{DB} \\
\mathrm{CO} \\
\mathrm{FMD}\end{array}$ & $\begin{array}{l}22 \text { patients } \\
\text { with } \mathrm{CHF}\end{array}$ & $\begin{array}{c}60.6 \pm 2.6 \text { years } \\
\text { Male } 91 \%\end{array}$ & $\begin{array}{l}\text { Rosuvastatin } 10 \mathrm{mg} / \text { day } \\
\text { Ezetimibe } 20 \mathrm{mg} / \text { day } \\
4 \text { weeks each arm }\end{array}$ & $\begin{array}{l}\text { The treatment of rosuvastatin, bu } \\
\text { not ezetimibe, improved FMD. }\end{array}$ \\
\hline $\begin{array}{l}\text { Mäki-Petäjä et al. } \\
{[125]}\end{array}$ & $\begin{array}{l}\mathrm{R}, \mathrm{DB} \\
\mathrm{CO} \\
\text { FMD }\end{array}$ & $\begin{array}{l}20 \text { patients } \\
\text { with RA }\end{array}$ & $\begin{array}{c}58 \pm 12 \text { years } \\
\text { Male } 20 \%\end{array}$ & $\begin{array}{l}\text { Simvastatin } 20 \mathrm{mg} / \text { day } \\
\text { Ezetimibe } 10 \mathrm{mg} / \text { day } \\
6 \text { weeks each arm }\end{array}$ & $\begin{array}{l}\text { The improvement in FMD by } \\
\text { simvastatin was greater, but no } \\
\text { significant, than that by } \\
\text { ezetimibe. }\end{array}$ \\
\hline
\end{tabular}




\begin{tabular}{|c|c|c|c|c|}
\hline Trial & Methods & Population & Protocol, Demographics & Endothelial function \\
\hline Ostad et al. [92] & $\begin{array}{l}\text { R, DB } \\
\text { FMD }\end{array}$ & $\begin{array}{l}49 \text { patients } \\
\text { with } \mathrm{CAD}\end{array}$ & $\begin{array}{l}\text { Atorvastatin } 80 \mathrm{mg} \text { /day ( } 24 \text { patients) } \\
66 \pm 9 \text { years, Male } 79 \% \\
\text { Atorvastatin } 10 \mathrm{mg} / \text { day }+ \text { ezetimibe } 10 \mathrm{mg} / \text { day ( } 25 \text { patients) } \\
64 \pm 10 \text { years, Male } 76 \% \\
\quad 8 \text { weeks }\end{array}$ & $\begin{array}{l}\text { The improvement in FMD by } \\
\text { atorvastatin was greater than the } \\
\text { combination therapy. }\end{array}$ \\
\hline $\begin{array}{c}\text { Settergren et al. } \\
{[89]}\end{array}$ & $\begin{array}{l}\mathrm{R}, \mathrm{DB} \\
\mathrm{FMD}\end{array}$ & $\begin{array}{l}39 \text { patients } \\
\text { with CAD } \\
\text { and } \\
\text { IGT/DM }\end{array}$ & $\begin{array}{l}\text { Simvastatin } 80 \mathrm{mg} / \text { day ( } 20 \text { patients) } \\
70 \text { years, Male } 75 \% \\
\text { Simvastatin } 10 \mathrm{mg} / \text { day + ezetimibe } 10 \mathrm{mg} / \text { day (19 patients) } \\
\quad 74 \text { years, Male } 58 \% \\
6 \text { weeks }\end{array}$ & $\begin{array}{l}\text { There was no difference in the } \\
\text { increase of FMD between the } \\
\text { two treatment groups. }\end{array}$ \\
\hline $\begin{array}{c}\text { Fichtlscherer et al. } \\
\qquad \text { [93] }\end{array}$ & FBF & $\begin{array}{l}60 \text { patients } \\
\text { with } \mathrm{CAD}\end{array}$ & $\begin{array}{l}\text { Ezetimibe } 10 \mathrm{mg} \text { /day de novo ( } 15 \text { patients) } \\
53.2 \pm 4.3 \text { years, Male: } 100 \% \\
\text { Ezetimibe } 10 \mathrm{mg} \text { /day added on simvastatin } 20 \mathrm{mg} / \text { day ( } 15 \text { patients) } \\
55.2 \pm 6.6 \text { years, Male: } 67 \% \\
\text { Atorvastatin } 10 \mathrm{mg} \text { /day } \rightarrow 40 \mathrm{mg} / \text { day ( } 15 \text { patients) } \\
56.5 \pm 3.9 \text { years, Male: } 80 \% \\
\text { Atorvastatin } 40 \mathrm{mg} \text { /day de novo ( } 15 \text { patients) } \\
56.5 \pm 2.8 \text { years, Male: } 100 \% \\
4 \text { weeks }\end{array}$ & $\begin{array}{l}\text { Only atorvastatin monotherapy } \\
\text { improved FBF }\end{array}$ \\
\hline
\end{tabular}




\begin{tabular}{|c|c|c|c|c|}
\hline & & & Simvastatin $10 \mathrm{mg} /$ day $(10$ patients $)$ \\
Landmesser et al. & $\mathrm{R}$ & 20 patients & Ezetimibe $10 \mathrm{mg} /$ day $(10$ patients $)$ \\
[91] & FDD & with CHF & $59 \pm 4$ years, Male $70 \%$ & The treatment of simvastatin, but \\
& & & $40 \%$ \\
\end{tabular}

FMD, flow-mediated vasodilatation in brachial artery; FDD, flow-dependent dilation in radial artery; FBF, forearm blood flow responded by acetylcholine R, randomized; DB, double-blind; CO, cross-over; Mets, metabolic syndrome; CHF, congestive heart failure; RA, rheumatoid arthritis; CAD, coronary artery disease; IGT, impaired glucose tolerance; DM, diabetes mellitus. 
Table 2. Comparison of effect on CRP of statin monotherapy and of statins combined with ezetimibe.

\begin{tabular}{|c|c|c|c|c|c|}
\hline Trial & Patients & Period & Medicine & Changes in LDL-C & Changes in CRP \\
\hline \multicolumn{6}{|c|}{ Statin monotherapy = Combination therapy with statin and ezetimibe } \\
\hline $\begin{array}{l}\text { Malmström } \\
\text { et al. [129] }\end{array}$ & $\begin{array}{c}32 \text { patients with } \\
\text { coronary artery disease }\end{array}$ & $\begin{array}{c}6 \\
\text { weeks }\end{array}$ & $\begin{array}{l}\text { Sim } 80 \mathrm{mg} \\
\text { Sim } 10 \mathrm{mg}+\mathrm{Ez} 10 \mathrm{mg}\end{array}$ & $\begin{array}{l}3.0 \pm 1.0 \rightarrow 1.4 \pm 0.5 \mathrm{mM} \\
3.2 \pm 0.6 \rightarrow 1.7 \pm 0.7 \mathrm{mM}\end{array}$ & $\begin{array}{l}3.8 \pm 3.2 \rightarrow 3.2 \pm 2.9 \mathrm{mg} / \mathrm{L} \\
4.8 \pm 4.5 \rightarrow 4.0 \pm 4.0 \mathrm{mg} / \mathrm{L}\end{array}$ \\
\hline $\begin{array}{l}\text { Ostad } \\
\text { et al. [92] }\end{array}$ & $\begin{array}{l}58 \text { patients with } \\
\text { coronary artery disease }\end{array}$ & $\begin{array}{c}8 \\
\text { weeks }\end{array}$ & $\begin{array}{l}\text { Ator } 80 \mathrm{mg} \\
\text { Ator } 10 \mathrm{mg}+\mathrm{Ez} 10 \mathrm{mg}\end{array}$ & $\begin{array}{l}-60 \pm 11 \% \\
-54 \pm 18 \%\end{array}$ & $\begin{array}{l}-1.9 \pm 1.9 \% \\
-1.8 \pm 2.1 \%\end{array}$ \\
\hline $\begin{array}{l}\text { Alvarez- } \\
\text { Sala et al. } \\
{[130]}\end{array}$ & $\begin{array}{c}82 \text { patients with } \\
\text { hypercholesterolemia }\end{array}$ & $\begin{array}{c}12 \\
\text { weeks }\end{array}$ & $\begin{array}{l}\text { Flu } 80 \mathrm{mg} \\
\text { Flu } 80 \mathrm{mg}+\mathrm{Ez} 10 \mathrm{mg}\end{array}$ & $\begin{array}{l}-35.2 \% \\
-49.9 \% *\end{array}$ & $\begin{array}{l}1.9 \pm 1.9 \rightarrow 1.9 \pm 2.2 \mathrm{mg} / \mathrm{L} \\
2.6 \pm 2.3 \rightarrow 2.1 \pm 1.9 \mathrm{mg} / \mathrm{L}\end{array}$ \\
\hline $\begin{array}{l}\text { Catapano } \\
\text { et al. [121] }\end{array}$ & $\begin{array}{l}\text { 2,959 patients with } \\
\text { hypercholesterolemia }\end{array}$ & $\begin{array}{c}6 \\
\text { weeks } \\
\end{array}$ & $\begin{array}{l}\text { Rosu 10, } 20 \mathrm{mg} \\
\text { Sim 20, } 40 \mathrm{mg}+\mathrm{Ez} 10 \mathrm{mg}\end{array}$ & $\begin{array}{l}-46 \sim 57 \% \\
-52 \sim 61 \% *\end{array}$ & $\begin{array}{l}-22.2 \% \\
-25.0 \%\end{array}$ \\
\hline $\begin{array}{l}\text { Ballantyne et } \\
\text { al. [131] }\end{array}$ & $\begin{array}{l}\text { 1,902 patients with } \\
\text { hypercholesterolemia }\end{array}$ & $\begin{array}{c}6 \\
\text { weeks } \\
\end{array}$ & $\begin{array}{l}\text { Ator 10, 20, 40, } 80 \mathrm{mg} \\
\text { Sim 10, 20, 40, } 80 \mathrm{mg}+\mathrm{Ez} 10 \mathrm{mg}\end{array}$ & $\begin{array}{l}-45.3 \% \\
-53.4 \% * \\
\end{array}$ & $\begin{array}{l}-25.1 \% \\
-24.8 \%\end{array}$ \\
\hline $\begin{array}{l}\text { Robinson } \\
\text { et al. [132] }\end{array}$ & $\begin{array}{l}\text { 1,128 patients with } \\
\text { hypercholesterolemia } \\
\text { and metabolic } \\
\text { syndrome }\end{array}$ & $\begin{array}{c}6 \\
\text { weeks }\end{array}$ & $\begin{array}{l}\text { Ator } 10,20 \mathrm{mg} \\
\text { Sim } 20 \mathrm{mg}+\mathrm{Ez} 10 \mathrm{mg} \\
\text { Ator } 40 \mathrm{mg} \\
\text { Sim } 40 \mathrm{mg}+\mathrm{Ez} 10 \mathrm{mg}\end{array}$ & $\begin{array}{c}-36.5 \sim 39.4 \% \\
-49.6 \% * \\
-46.0 \% \\
-53.9 \% *\end{array}$ & $\begin{array}{c}-16.8 \sim 22.4 \% \\
-17.2 \% \\
-30.0 \% \\
-27.6 \%\end{array}$ \\
\hline $\begin{array}{c}\text { Leiter } \\
\text { et al. [133] }\end{array}$ & $\begin{array}{c}579 \text { patients with } \\
\text { hypercholesterolemia }\end{array}$ & $\begin{array}{c}6 \\
\text { weeks }\end{array}$ & $\begin{array}{l}\text { Ator } 40 \mathrm{mg} \rightarrow 80 \mathrm{mg}(+40 \mathrm{mg}) \\
\text { Ator } 40 \mathrm{mg}+\mathrm{Ez} 10 \mathrm{mg}\end{array}$ & $\begin{array}{l}-11 \% \\
-27 \% *\end{array}$ & $\begin{array}{l}-11 \% \\
-18 \%\end{array}$ \\
\hline $\begin{array}{l}\text { Conard } \\
\text { et al. }[134]\end{array}$ & $\begin{array}{c}196 \text { patients with } \\
\text { hypercholesterolemia }\end{array}$ & $\begin{array}{c}6 \\
\text { weeks }\end{array}$ & $\begin{array}{l}\text { Ator } 20 \mathrm{mg} \rightarrow 40 \mathrm{mg}(+20 \mathrm{mg}) \\
\text { Ator } 20 \mathrm{mg}+\mathrm{Ez} 10 \mathrm{mg}\end{array}$ & $\begin{array}{c}-11 \% \\
-31 \% *\end{array}$ & $\begin{array}{l}-9 \% \\
-7 \%\end{array}$ \\
\hline
\end{tabular}




\begin{tabular}{|c|c|c|c|c|c|}
\hline \multicolumn{6}{|c|}{ Statin monotherapy > Combination therapy with statin and ezetimibe } \\
\hline $\begin{array}{c}\text { Efrati } \\
\text { et al. [119] }\end{array}$ & $\begin{array}{c}40 \text { patients with } \\
\text { hypercholesterolemia }\end{array}$ & $\begin{array}{c}3 \\
\text { months }\end{array}$ & $\begin{array}{l}\operatorname{Sim} 40 \mathrm{mg} \\
\operatorname{Sim} 40 \rightarrow 80 \mathrm{mg} \\
\text { Ez } 10 \mathrm{mg} \\
\text { Sim } 40 \mathrm{mg}+\text { Ez } 10 \mathrm{mg}\end{array}$ & $\begin{array}{l}-40 \pm 4 \% \\
-17 \pm 19 \% \\
-18 \pm 13 \% \\
-36 \pm 17 \%\end{array}$ & $\begin{array}{c}2.8 \pm 2.5 \rightarrow 1.6 \pm 1.5 \mathrm{mg} / \mathrm{L}^{\ddagger} \\
1.98 \pm 2.2 \rightarrow 1.2 \pm 0.8 \mathrm{mg} / \mathrm{L} \\
2.4 \pm 1.2 \rightarrow 2.7 \pm 2.2 \mathrm{mg} / \mathrm{L} \\
2.1 \pm 1.8 \rightarrow 1.57 \pm 1.2 \mathrm{mg} / \mathrm{L}\end{array}$ \\
\hline \multicolumn{6}{|c|}{ Combination therapy with statin and ezetimibe $>$ Statin monotherapy } \\
\hline $\begin{array}{l}\text { Ballantyne et } \\
\text { al. [120] }\end{array}$ & $\begin{array}{c}469 \text { patients with } \\
\text { hypercholesterolemia }\end{array}$ & $\begin{array}{c}6 \\
\text { weeks }\end{array}$ & $\begin{array}{l}\text { Rosu } 40 \mathrm{mg} \\
\text { Rosu } 40 \mathrm{mg}+\mathrm{Ez} 10 \mathrm{mg}\end{array}$ & $\begin{array}{l}-57 \% \\
-70 \% *\end{array}$ & $\begin{array}{l}-29 \% \\
-46 \% *\end{array}$ \\
\hline $\begin{array}{l}\text { Sager } \\
\text { et al. [135] }\end{array}$ & $\begin{array}{c}\text { 1,089 patients with } \\
\text { hypercholesterolemia }\end{array}$ & $\begin{array}{c}12 \\
\text { weeks }\end{array}$ & $\begin{array}{l}\operatorname{Sim} 10,20,40,80 \mathrm{mg} \\
\operatorname{Sim} 10,20,40,80 \mathrm{mg}+\operatorname{Ez} 10 \mathrm{mg}\end{array}$ & $\begin{array}{l}-37.5 \% \\
-52.3 \%^{\dagger}\end{array}$ & $\begin{array}{l}-14.3 \% \\
-33.3 \%^{\dagger}\end{array}$ \\
\hline $\begin{array}{l}\text { Goldberg } \\
\text { et al. [136] }\end{array}$ & $\begin{array}{c}887 \text { patients with } \\
\text { hypercholesterolemia }\end{array}$ & $\begin{array}{c}12 \\
\text { weeks }\end{array}$ & $\begin{array}{l}\operatorname{Sim} 10,20,40,80 \mathrm{mg} \\
\operatorname{Sim} 10,20,40,80 \mathrm{mg}+\operatorname{Ez} 10 \mathrm{mg}\end{array}$ & $\begin{array}{l}-38.5 \% \\
-53.2 \% *\end{array}$ & $\begin{array}{c}-8.7 \% \\
-33.3 \% *\end{array}$ \\
\hline $\begin{array}{c}\text { Bays } \\
\text { et al. [137] }\end{array}$ & $\begin{array}{c}\text { 1,528 patients with } \\
\text { hypercholesterolemia }\end{array}$ & $\begin{array}{c}12 \\
\text { weeks }\end{array}$ & $\begin{array}{l}\operatorname{Sim} 10,20,40,80 \mathrm{mg} \\
\operatorname{Sim} 10,20,40,80 \mathrm{mg}+\mathrm{Ez} 10 \mathrm{mg}\end{array}$ & $\begin{array}{l}-39.0 \% \\
-53.0 \% *\end{array}$ & $\begin{array}{l}-16.7 \% \\
-31.0 \% *\end{array}$ \\
\hline $\begin{array}{c}\text { Ballantyne et } \\
\text { al. [14] }\end{array}$ & $\begin{array}{c}628 \text { patients with } \\
\text { hypercholesterolemia }\end{array}$ & $\begin{array}{c}12 \\
\text { weeks }\end{array}$ & $\begin{array}{l}\text { Ator 10, 20, 40, } 80 \mathrm{mg} \\
\text { Ator 10, 20, 40, } 80 \mathrm{mg}+\mathrm{Ez} 10 \mathrm{mg}\end{array}$ & $\begin{array}{l}-42.4 \pm 0.95 \% \\
-54.5 \pm 0.94 \%{ }^{\dagger}\end{array}$ & $\begin{array}{l}-31 \% \\
-41 \%{ }^{\dagger}\end{array}$ \\
\hline $\begin{array}{l}\text { Gagné } \\
\text { et al. [16] }\end{array}$ & $\begin{array}{c}769 \text { patients with } \\
\text { hypercholesterolemia }\end{array}$ & $\begin{array}{c}8 \\
\text { weeks }\end{array}$ & $\begin{array}{l}\text { Statins + placebo } \\
\text { Statins + Ez } 10 \mathrm{mg}\end{array}$ & $\begin{array}{c}-3.7 \% \\
-25.0 \% *\end{array}$ & $\begin{array}{c}0 \% \\
-9.7 \%\end{array}$ \\
\hline
\end{tabular}

Ez, Ezetimibe; Sim, Simvastatin; Ator, Atorvastatin; Flu, Fluvastatin; Ros, Rosuvastatin. ${ }^{*} \mathrm{p}<0.001 ;{ }^{\dagger} \mathrm{p}<0.01,{ }^{\dagger} \mathrm{p}<0.05$. 